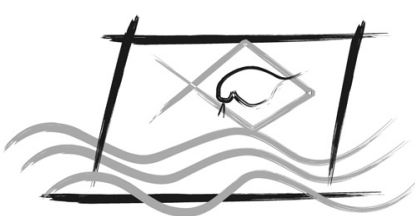

J. Braz. Soc. Ecotoxicol., v. 7, n. 2, 2012, 67-72

doi: $10.5132 / j b s e .2012 .02 .010$

ECOTOX - BRASIL

\title{
Water toxicity and cyto-genotoxicity biomarkers in the fish Oreochromis niloticus (CICHLIDAE)
}

\author{
R. Seriani ${ }^{1,2}$; D.M.S. Abessa ${ }^{1}$; A.A. Kirschbaum ${ }^{3}$; C.D.S. Pereira ${ }^{3}$; M.J.T. Ranzani-Paiva ${ }^{2}$; A. \\ AsSUnÇã̃o $;$ F.L. SilveirA'; P. Romano ${ }^{1} \&$ J.L.N. MuCCI ${ }^{4}$ \\ ${ }^{1}$ Nucleo de Estudos de Poluição e Ecotoxicologia Aquática - Universidade Estadual Paulista - Campus do Litoral Paulista - São Vicente - SP. \\ ${ }^{2}$ Centro de Pesquisas e Desenvolvimento de Peixes Ornamentais - Instituto de Pesca- São Paulo - SP. \\ ${ }^{3}$ Laboratório de Ecotoxicologia Prof. Caetano Belliboni - Universidade Santa Cecília - Santos - SP. \\ ${ }^{4}$ Departamento de Saúde Ambiental Faculdade de Saúde Pública - Universidade de São Paulo - São Paulo - SP
}

(Received June 02, 2010; Accept August 29, 2011)

\begin{abstract}
Micronucleus (MN) and nuclear abnormalities (NA) tests were used as biomarkers in the fish Oreochromis niloticus from a polluted pond in winter, spring and summer. Samples of water column were taken aiming to evaluate physical-chemical parameters and acute toxicity to the microcrustacean Daphnia similis. The pond waters were toxic to D. similis in spring and winter, but this toxicity was not detected in summer. The pond waters presented low levels of dissolved oxygen in spring and summer; higher ammonia concentrations in winter, and high hardness and conductivity. Fish collected at the polluted pond exhibited higher rates of DNA damage, as indicated by increased rates of MN and NA in erythrocytes when compared to the negative control, which were associated to water toxicity and physical-chemical variable. Thus, this study shows that results of water toxicity tests and genotoxic biomarkers in fish may be associated and theses approaches may be used together for the water quality assessment.
\end{abstract}

Keywords: fish, cyto-genotoxicity, pollution, ecotoxicology, water quality.

\section{Toxicidade da água e biomarcadores de citogenotoxicidade em Oreochromis niloticus (CICHLIDAE)}

\begin{abstract}
Resumo
No presente estudo foi utilizado o teste do micronúcleo (MN) e de anomalias na morfologia dos núcleos de eritrócitos periféricos (NA) do peixe Oreochromis niloticus para avaliar o potencial cito-genotóxico de substâncias tóxicas encontradas na água durante inverno, primavera e verão em um lago poluído. Amostras de água foram coletadas para avaliar parâmetros físico-químicos e toxicidade aguda para o microcrustáceo Daphnia similis. Os resultados indicaram baixos teores de oxigênio dissolvido na água durante a primavera e no verão, elevados níveis de amônia no inverno, além de dureza e condutividade altas e toxicidade aguda na primavera e no inverno, não assim no verão. Os peixes também apresentaram danos cito-genotóxicos, em todas as coletas, e que foram associados com a toxicidade e os parâmetros físico-químicos da água. Nesse sentido o presente estudo mostra que os resultados de testes de toxicidade aguda e de biomarcadores de cito-genotóxicidade em peixes podem estar associados e podem ser utilizados de forma conjunta para na avaliação da qualidade das águas.
\end{abstract}

Palavras-chave: peixes, cito-genotoxicidade, poluição, ecotoxicologia, qualidade de água. 


\section{INTRODUCTION}

The aquatic environment receives a variety of organic and inorganic substances from natural or anthropogenic sources, which may induce damages to the aquatic biota at molecular, biochemical, cellular and physiological levels (Rand, 1995). Thus, these inputs may represent a threat to aquatic ecosystems, to the preservation of ecological processes and to fisheries and aquaculture resources.

The continuous input of pollutants into the environment has led to the development of many different techniques to evaluate and monitor their fate and effects (Rand, 1995). Sentinel organisms for the biological monitoring of environmental quality provide a sensitive and reliable approach to estimate the potential effects of pollutants (Farrington \& Tripp, 1995). A wide variety of organisms has been used to monitor areas with different pollution levels. Among them, fishes represent excellent experimental models for toxicological studies, providing early warning for pollution-induced environmental changes (Powers, 1989). According to Harshbarger \& Clark (1990) fish are exposed to the xenobiotics in similarly manner as other vertebrates, and may be used to evaluate the potential of some contaminants to produce teratogenic and carcinogenic effects in humans.

Genotoxicity studies using cytogenetic analyses in fish have demonstrated the sensitivity of these organisms (AlSabti \& Metcalfe, 1995). Among the currently available procedures, micronuclei and nuclear abnormalities assays are the most widely applied methods due to its proven suitability for fish species (Al-Sabti, 1991; Cavas \& ErgeneGozukara, 2003, Kirschbaum et al. 2009). Micronuclei are cytoplasm chromatin masses with the appearance of small nuclei that arise from chromosome fragments or intact whole chromosomes that lagged behind in the anaphase stage of cell division. Their presence in cells is a result of structural and/or numerical chromosomal aberrations arising during mitosis (Heddle et al., 1991). Micronuclei assay detects both clastogenic and aneugenic effects and therefore can detect the genotoxicity of a wide range of compounds (Heddle et al., 1991). Nuclear abnormalities, such as micronuclei and other nuclear malformations, are considered good indicators of cytotoxicity and genotoxicity, respectively (Hose et al., 1987; Metcalfe, 1988; Pacheco \& Santos, 1996, 1997, 1998; Sanchez-Galan et al., 1998; Ayllon \& Garcia-Vazquez, 2000; Ayllon \& Garcia-Vasquez, 2001, Kirschbaum, et al., 2009).

In field and laboratory conditions, increased frequencies of micronuclei in fish cells have been observed after exposure to different chemicals and complex mixtures (Al-Sabti \& Metcalfe, 1995; Kirschbaum et al., 2009). However, the presence of cellular and/or cytogenetic effects does not always indicate low environmental quality, since they can be produced by natural stress. Moreover, organisms present efficient repair systems, so that these effects may not affect the organism health at all. Thus, it is necessary to use additional methods to confirm if contamination is effectively impairing the health of aquatic biota.
Along with biomarkers, toxicity tests which are employed to identify responses at population or sub-population levels are also useful to estimate possible disturbances in ecosystems (Chapman \& Long, 1983). Planktonic cladocerans have an important role in the food chain, because they feed on algae and constitute food for secondary consumers. Alterations in the cladocerans natural populations may provide evidences of ecological disturbances and possible effects on the trophic structure of the aquatic ecosystem (Knie \& Lopes, 2004).

Due to their proximity to cities and other man made structures, reservoirs, creeks, urban ponds and other water bodies commonly receive the discharges of many classes of contaminants, which can affect the biota. In addition to that, aesthetical and recreational attributes are affected by fish mortality, release of sulfides and cyanobacteria blooms (Seriani et al., 2005)

The present study aimed to evaluate the quality of the water from Girassol Pond (GP) through the analysis of physicalchemical parameters of the water, toxicity tests with Daphnia similis and the analysis of cyto-genotoxic biomarkers in the fish Oreochromis niloticus.

\section{MATERIAL AND METHODS}

The study area, Girassol Pond (GP), is located in Santo André, in the State of São Paulo, Brazil (2337'53"S, $\left.46^{\circ} 31^{\prime} 58.73^{\prime \prime} \mathrm{W}\right)$. Due to its proximity to residential areas, this pond receives discharges of domestic effluents and storm water, which eventually result in algal blooms. Despite the lack of previous studies on GP, episodes of massive mortalities of fish are well known and have been already reported, and have been attributed to cyanobacteria like Microcistys aeruginosa, Cylindrospermopsis raciborskii and Anabaena flosaquae (Seriani et al., 2005).

The renewal of the water in the pond is very low and depends exclusively on pluviometric rates. The pond fauna exhibits low diversity, with Oreochromis niloticus (Cichlidae) as the dominant species. O. niloticus individuals were artificially introduced into GP along with some smaller fish, such as ornamental guppies Poecilia reticulata.

In order to evaluate the effects of pollutants present in GP, healthy organisms obtained from an experimental fish farm were used as the experimental control group for the genotoxic analysis, toxicity tests and physical-chemistry of water. This farm belongs to the Fisheries Institute of the State of São Paulo (Instituto de Pesca do Estado de São Paulo - IP/SAA-APTA). The water conditions in the culture tanks are considered adequate (Boyd, 1990; Conama, 2005) and the fishes were considered healthy (Seriani et al., 2009). This farm is used in many different research projects and is considered as a standard in Brazil. Water samples and individuals of $O$. niloticus were collected in winter, spring and summer in GP. Young fish of comparable age and size to the animals analyzed in the other seasons were not available at the Farm (control) in autumn. Therefore, no sampling was performed in this season. 
Surface water samples were collected using buckets, transferred to glass flasks and stored frozen till the beginning of toxicity tests. Before freezing and after thawing, the following physical-chemical parameters of the samples were analyzed according to APHA (2005): conductivity $\left(\mu \mathrm{S} \mathrm{cm}^{-1}\right)$, temperature $\left({ }^{\circ} \mathrm{C}\right), \mathrm{pH}$, hardness $(\mathrm{mg}$ $\left.\mathrm{CaCo}_{3} \mathrm{~L}^{-1}\right)$ and dissolved oxygen content $\left(\mathrm{mg} \mathrm{L}^{-1}\right)$. The total ammonia concentration $\left(\mathrm{NH}_{3}-\mathrm{NH}_{4}\right)$ was measured by the colorimetric method (Koroleff, 1970). Unionized ammonia concentrations were estimated by the method reported by Whitfield (1974), using measured $\mathrm{pH}$, temperature, conductivity and total ammonia data.

Acute toxicity tests with Daphnia similis were conducted with water samples collected concomitantly to the fish. Neonate individuals of $D$. similis were exposed to the whole samples and immobile organisms were counted after a $48 \mathrm{~h}$ exposure. The tests were performed according to the ABNT12713 protocol (1993). A dilution series $(100 \%, 50 \%, 25 \%$, $12.5 \%$, and $6.25 \%$ ) was tested. Culture water was used to dilute the samples. The choice for using dilutions was based in a pilot experiment which indicated strong acute toxicity of GP waters and allowed the comparison of the toxic potential of waters by the calculation of Effective Concentrations to $50 \%$ exposed organisms after $48 \mathrm{~h}$ exposure (EC50-48 h), by using the Trimmed Spearman-Karber method (Hamilton et al., 1977). Besides, the results obtained in each concentration were compared to the control by analysis of variance (ANOVA) followed by Dunnett's test (Zar, 1984). Significance level $(\alpha)$ was fixed in 0.05 .

In each sampling campaign, seven individuals of O. niloticus $(\mathrm{Wt}=180 \pm 20 \mathrm{~g}$ and $\mathrm{Lt}=18.0 \pm 3 \mathrm{~cm}$ ) were collected. Before the use, fishes were anesthetized with clove oil $0.04 \%$, prepared by solving $0.4 \mathrm{ml}$ oil in $3.6 \mathrm{~mL}$ ethanol and diluting this solution in $1 \mathrm{~L}$ distilled water (Delbon, 2006; Kirschbaum et al., 2009). Blood samples were taken by caudal punction using previously heparinized needles and syringes. Blood extensions were prepared in glass slides and colored with May-Grünwald-Giemsa (Rosenfeld, 1947; Kirschbaum et al., 2009). Two thousand cells were analyzed per slide/animal under a compound microscope $(1,000 \mathrm{x})$ and the micronuclei (MN) and nuclear abnormalities (NA) according to Çavas \& Ergene-Gözükara $(2003 ; 2005)$ and Kirschbaum et al. (2009). The cyto-genotoxicity biomarkers were expressed as mean \pm standard error (S.E.) and statistical analysis was performed using a two-tailed Student's t-test (control vs. GP) ( $\alpha=0.05)$.

To analyze the existence of relationships between cytogenotoxicity responses and water quality, the data of the three collections were jointly submitted to a non-parametrical ordination analysis (Multi-Dimensional Scaling - MDS) coupled to a Monte Carlo test. This analysis used two data matrices: the first contained the cyto-genotoxicity data, and the second consisted of the water quality descriptors (acute toxicity and physical-chemical parameters). The data were $\log _{n}$-transformed before the analysis.

\section{RESULTS}

\section{Water quality: physical-chemical parameters}

The water physical-chemical parameters are shown in Table 1. The $\mathrm{pH}$ in GP ranged from 6.6 to 7.6 , whereas in the control it ranged from 7.1 to 7.6. In all the sample collections, hardness of GP waters was higher than the controls' in all samples (110-149 and 22-31 $\mathrm{mg} \mathrm{CaCO}_{3} \mathrm{~L}^{-1}$, respectively). Dissolved oxygen content in GP water was variable, ranging from 1.5 to $7.5 \mathrm{mg} \mathrm{L}^{-1}$, whereas in the control the values were high (5.5 to $\left.6.7 \mathrm{mg} \mathrm{L}^{-1}\right)$. The conductivity of GP waters was much higher than that of control waters, reaching values above $400 \mu \mathrm{S} \mathrm{cm}^{-1}$. In situ temperatures were variable in GP (20.0 to $26.9^{\circ} \mathrm{C}$ ) and more homogenous in the controls (20.0 to 22.0 ${ }^{\circ} \mathrm{C}$ ). Total ammonia concentrations in GP ranged from 0.25 to $3.96 \mathrm{mg} \mathrm{L}^{-1}$, with unionized ammonia concentration ranging from 0.01 to $0.07 \mathrm{mg} \mathrm{L}^{-1}$. In the controls, total and unionized ammonia concentrations were low.

\section{Water toxicity}

The toxicity test with $D$. similis exhibited acute toxicity in GP waters in the winter and spring; acute toxicity was not observed in the summer samples. The conditions in the spring $\left(\mathrm{EC}_{50-48 \mathrm{~h}}=77.1 \% ; 95 \%\right.$ confidence interval: $\left.70.0-84.9 \%\right)$

Table 1 - Physical-chemical parameters of water from Girassol Pond and the control group in different seasons.

\begin{tabular}{|c|c|c|c|}
\hline Physical-chemical parameters & Winter & Spring & Summer \\
\hline \multicolumn{4}{|l|}{$\mathrm{pH}$} \\
\hline Girassol lake & 7,6 & 6,6 & 7 \\
\hline Control & 7,1 & 7,6 & 7,3 \\
\hline \multicolumn{4}{|l|}{ Hardness $\left(\mathrm{CaCo}_{3}\right) \mathrm{mg} / \mathrm{l}$} \\
\hline Girassol lake & 149 & 110 & 120 \\
\hline Control & 22 & 31 & 27 \\
\hline \multicolumn{4}{|l|}{ Dissolved oxygen (mg/l) } \\
\hline Girassol lake & 7,5 & 1,5 & 1,5 \\
\hline Control & 5,5 & 6,7 & 6 \\
\hline \multicolumn{4}{|l|}{ Condutivity (uS/cm) } \\
\hline Girassol lake & 427 & 495 & 400 \\
\hline Control & 61 & 21 & 68 \\
\hline \multicolumn{4}{|l|}{ Temperatue $\left({ }^{\circ} \mathrm{C}\right)$} \\
\hline Girassol lake & 20 & 24,1 & 26,9 \\
\hline Control & 20 & 21 & 22 \\
\hline \multicolumn{4}{|l|}{ Total ammonia (mg/l) } \\
\hline Girassol lake & 3,96 & 0,25 & 1,5 \\
\hline Control & 0,01 & 0,01 & 0,01 \\
\hline \multicolumn{4}{|l|}{ Unionized ammonia $\left(\mathrm{NH}_{3}\right)$} \\
\hline Girassol lake & 0,07 & 0,05 & 0,01 \\
\hline Control & 0,01 & 0,001 & 0,001 \\
\hline
\end{tabular}


were slightly more toxic than in the winter $\left(\mathrm{EC}_{50-48 \mathrm{~h}}=84.1 \%\right.$; 95\% confidence interval: $69.7-101.4 \%$ ).

\section{Genotoxicity}

Micronuclei and Nuclear abnormalities are represented in Figure 1. Significant differences $(p<0.05)$ between the GP and the control were not observed for MN and NAs in all the studied seasons. As shown by the standard deviations, the MN and NA rates in GP varied greatly, which may explain the absence of differences between GP and controls. However, some not statistically significant trends could be detected and should be mentioned. Fish from GP exhibited measurable rates of $\mathrm{NA}$ and $\mathrm{MN}$ in summer and spring, whereas in fish from the farm (control) the NA and MN rates were zero.

\section{Multivariate analysis}

The Monte Carlo test showed that the stress in real data was smaller than the stress in randomized data. The axis 1 of the MDS was negatively correlated to water $\mathrm{pH}(-0.44)$, and positively correlated to hardness $(0.58)$, conductivity $(0.63)$, total and unionized ammonia ( 0.46 and 0.47 , respectively) and water toxicity $(0.40)$. This axis essentially indicated the association between water physical-chemistry and toxicity. Axis 2 showed positive correlation to dissolved oxygen and
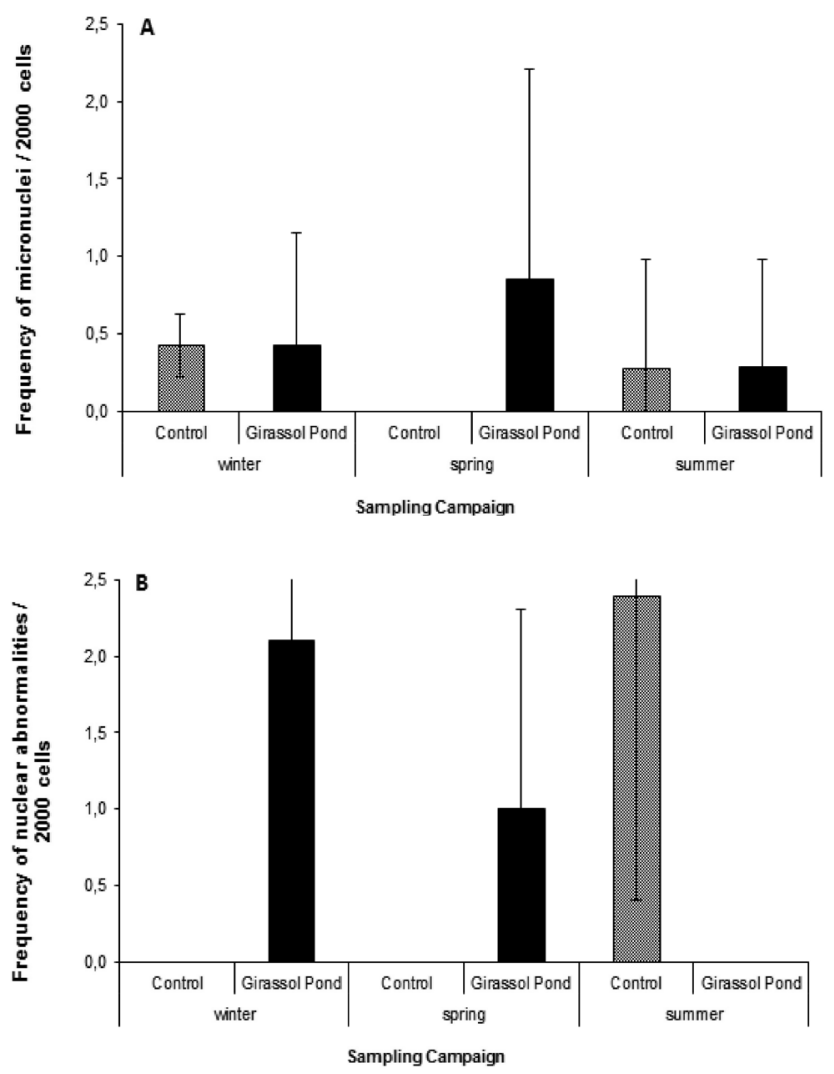

Figure 1 - Mean values and standard deviations of micronuclei (A) and nuclear abnormality $(\mathrm{B})$ in erythrocytes of $O$. niloticus collected at Girassol Pond and Control. negative correlations to water hardness $(-0.92)$, conductivity $(-0.95)$, temperature $(-0.66)$, total and unionized ammonia $(-0.56$ and -0.77 , respectively), water toxicity $(-0.73)$ and Micronuclei rates $(-0.59)$. The axis 2 showed the association between water physical-chemical factors, toxicity and genotoxic effects. The MDS correlations are showed in the Table 2. Regarding to the sampling stations, all the GP campaigns were negatively associated to axis 2 , whereas the winter and summer controls were also associated to the axis 2 of the MDS and the spring was negatively associated to axis 1 (Fig. 2).

Thus these results show the existence of an association of the biological responses in nuclear markers and water toxicity and physical-chemical parameters (ammonia, conductivity, hardness).

When the MDS is interpreted together with the result of each analyzed variable, it is possible to see that controls and GP campaigns were clearly separated. Water conditions are clearly different between sites, occurring acute toxicity in GP during spring and winter. Blood of fishes seems to respond to such differences, and animals from GP exhibit higher MN rates.

Table 2 - Multi-Dimensional Scalling correlations for variables and the two first axes (gray cells indicate stronger correlations).

\begin{tabular}{lcc}
\hline Variable & Axis 1 & Axis 2 \\
\hline $\mathrm{pH}$ & -0.442 & 0.358 \\
Hardness $\left(\mathrm{CaCO}_{3}\right)$ & 0.580 & -0.922 \\
Dissolved Oxygen & -0.358 & 0.526 \\
Conductivity & 0.632 & -0.951 \\
Temperature & 0.371 & -0.656 \\
$\mathrm{NH}_{3}-\mathrm{NH}_{4}^{+}$ & 0.464 & -0.560 \\
$\mathrm{NH}_{3}$ & 0.467 & -0.765 \\
$\mathrm{Toxicity}^{+}($D. similis $)$ & 0.403 & -0.730 \\
$\mathrm{MN}$ & 0.222 & -0.599 \\
$\mathrm{NA}$ & 0.063 & 0.061 \\
\hline
\end{tabular}

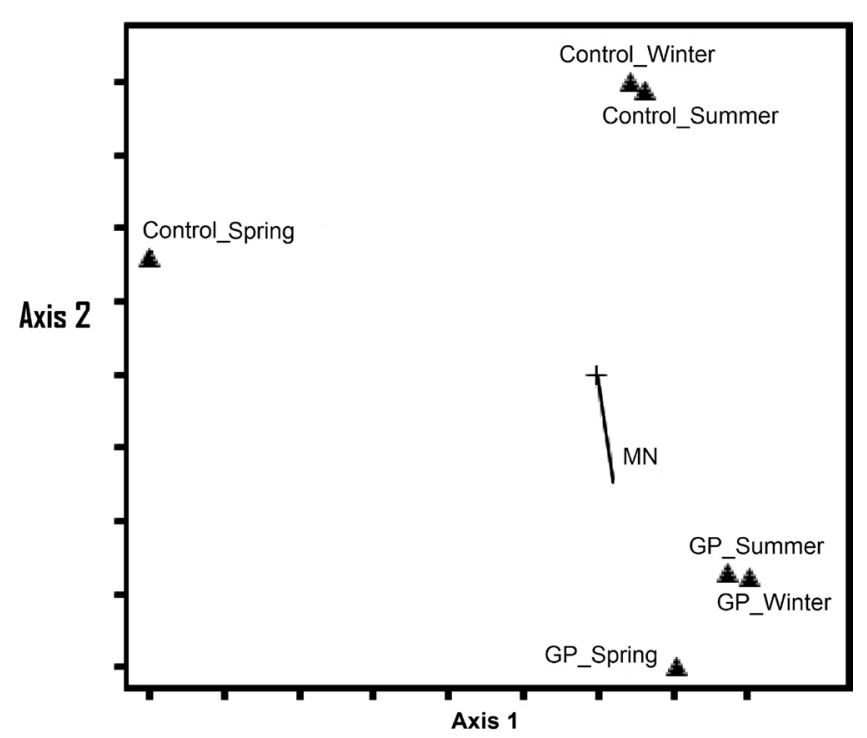

Figure 2 - Multi-Dimensional Scaling, reduced to 2 dimensions, with physical-chemical data, water toxicity and cyto-genotoxicity responses of $O$. niloticus from Girassol Pond and control. 


\section{Discussion}

In environmental monitoring, is desirable the use of biological methods that are easy, cheap and strongly related to contaminant levels. However, these biological methods exhibit a wide natural variability and are influenced by several natural factors, which may difficult the data interpretation. In such cases, it is important not only to compare each set of data, but if possible, apply mathematic or statistical techniques that allow an overall analysis of the whole dataset (Chapman, 1990).

In the present study a strong association between the water quality and the chosen biomarkers (MN and NA) and acute toxicity for $D$. similis was observed. The relationship between water toxicity, ammonia and conductivity suggests that contaminants associated to sewage affected the water quality.

Conductivity was higher in the dry season (e.g., winter) and lower in the wet season (e.g. summer), which suggests that temporal variations in this variable can be attributed to pluviometric precipitation rates: the higher the precipitation rate, the higher the pond's capability to dilute ions. Similar diluting phenomenon during rainy period was observed in urban water bodies (Abessa, 2003), causing decrease in conductivity and ions concentrations (Cruz et al., 2007). A similar phenomenon may have occurred for ammonia, for which higher concentrations were observed in the dry season. Moreover, the association of toxicity and biological responses to water hardness suggests that natural factors can influence such responses or that $\mathrm{CaCO}_{3}$ is discharged into the lake with the sewage. Therefore, further studies are required to explain this.

Moreover, although not demonstrated, the MN rates followed the same trend exhibited by water toxicity, i.e., when the GP waters were toxic MNs were present in O. niloticus. Although the $\mathrm{MN}$ rates in $O$. niloticus from GP were not very high when compared to the literature (Al-Sabti \& Metcalfe, 1995; ErgeneGözükara, et al. 2001) they were absent in clean conditions. NA rates, on the other hand, did not exhibit significant differences between GP and control fish, or even along time, but exhibited a trend similar to that shown by the MN.

According to many authors (Hooftman \& de Raat, 1982; Hose et al., 1987; Pacheco \& Santos, 1997; Ayllon \& GarciaVazquez, 2000; Ayllon \& Garcia-Vazquez, 2000; Gravato \& Santos, 2002; Kirschbaum et al., 2009) the observation of variations in the nucleus shape could represent an alternative approach to detect cyto-genotoxicity. Preliminary observations strongly suggest that such morphological alterations may be a manifestation of the effects of xenobiotics (Ayllon \& GarciaVazquez, 2000; Gravato \& Santos, 2002; Kirschbaum, et al., 2009). It has been suggested that in genotoxicity studies with fish, both alterations in nuclear morphology and micronuclei number should be considered when using the micronuclei test (Al-Sabti \& Metcalfe, 1995; Pacheco \& Santos, 1997; Ayllon \& Garcia-Vazquez, 2000; Gravato \& Santos, 2002; Kirschbaum et al., 2009). Recently, nuclear abnormalities (NA) in erythrocytes were considered a useful parameter for assessing the genotoxic effects of environmental pollutants in fish, and have been applied with success in different species such as Anguilla anguilla (Pacheco \& Santos, 1997), Dicentrarchus labrax (Gravato \& Santos, 2002), Oncorhynchus mykiss (Ayllon \& Garcia-Vasquez, 2001) and Centropomus parellelus (Kirschbaum et al., 2009). According to Metcalfe (1988); Pacheco \& Santos (1996; 1997; 1998); Sanchez-Galan et al. (1998); Ayllon \& Garcia-Vazquez (2000) and Kirschbaum et al. (2009), these alterations of the nuclear morphology may be considered of genotoxic origin. The correlation of $\mathrm{NA}$ and $\mathrm{MN}$ rates with water toxicity, conductivity and ammonia concentrations suggests that such increased NA and MN rates in fish from GP may be caused by contaminants (including the ammonia itself). Several classes of contaminants are frequently associated to sewage, as ammonia, metals, sulphur, nitrates and nitrites, oil and greases, suspended solids and detergents, among others (Abessa et al., 2005; Pereira et al., 2007). The biochemical metabolic ways to detoxify contaminants sometimes may produce reactive oxygen species (ROS) and cause membrane lipo-peroxidation (Livingstone, 2001). Thus, affected membranes may allow the contaminants to reach the nucleus, deeming the DNA more susceptible to contaminants.

Since $O$. nilotucus is frequently cultured in Brazilian rivers, reservoirs and artificial tanks ("floating-cage" systems), biomarker studies with this species can be easily integrated with toxicity bioassays in wide programs for monitoring water quality.

In summary, cytogenotoxic effects in O. niloticus were associated to toxicity and physical-chemical changes in waters from GP, indicating that this environment is degraded and does not present suitable conditions for aquatic life.

\section{ACKNOWLEDGEMENTS}

To members of the Laboratory of Ecotoxicology (UNISANTA), in special to Dr. Augusto Cesar, for the technical support, suggestions and critical review of this investigation; to Drs. Wanda M.R. Ghünter and João Vicente de Assunção (Faculdade de Saúde Pública - USP) and Marion Nipper (Texas A\&M University) for reviewing the manuscript; to the fishermen who helped us obtaining $O$. niloticus, in special to Mr. Antônio; and to the farm administrators, Mr. Ari and Mr. Grava for their help.

\section{REFERENCES}

ABESSA, D.M.S. 2003, Avaliação da qualidade da água do Rio Pirajussara (São Paulo-SP): primeiros resultados. O Mundo da Saúde, 27( 4): 543-550.

ABESSA, D.M.S.; CARR, R.S.; RACHID, B.R.F.; SOUSA, E.C.P.M.; HORTELANI, M.A. \& SARKIS, J.E. 2005, Influence of a Brazilian sewage outfall on the toxicity and contamination of adjacent sediments. Mar. Poll. Bull., 50: 875-885. doi:10.1016/j. marpolbul.2005.02.034

AL-SABTI, K. 1991, Handbook of genotoxic effects and fish chromosomes. Joseph Stephane Institute, Ljubljiana, Yugoslavia, $222 \mathrm{p}$.

AL-SABTI, K. \& METCALFE, C.D. 1995, Fish micronuclei for assessing genotoxicity in water. Mut. Research, 343: 121-135. doi:10.1016/0165-1218(95)90078-0 
APHA; AWWA; WPCF. 2005, Standard Methods for the examination of Water and Wastewater. 21 ${ }^{\text {a }}$ Ed., Washington, DC., APHA - American Public Health Association, AWWA - American Water Works Association and WPCF - Water Pollution Control Federation.

AYLLON, F. \& GARCIA-VAZQUEZ, E. 2000, Induction of micronuclei and other nuclear abnormalities in European minnow Phoxinus phoxinus and mollie Poecilia latipinna: an assessment of the fish micronucleus test. Mut. Res., 467: 177186. doi:10.1016/S1383-5718(00)00033-4

AYLLON, F. \& GARCIA-VAZQUEZ, E. 2001, Micronuclei and other nuclear lesions as genotoxicity indicators in rainbow trout Oncorhynchus mykiss. Ecotox. Environ.Saf., 49: 221-225. doi:10.1006/eesa.2001.2065

BOYD, C. 1990, Water quality in ponds for aquaculture. London: Birmingham, 482p.

ÇAVAS, T. \& ERGENE-GOZUKARA, S. 2003, Evaluation of the genotoxic potential of lambda-cyhalothrin using nuclear and nucleolar biomarkers on fish cells. Mut. Res., 534 (1-2): 93-99.

ÇAVAS T. \& ERGENE-GÖZÜKARA S. 2005, Induction of micronuclei and nuclear abnormalities in Oreochromis niloticos following exposure to petroleum refinery and chromium processing plant effluents. Aq. Toxicol., 74: 264-271.

CHAPMAN, P.M. 1990, The sediment quality triad approach to determining pollution-induced degradation. Sc. Total Environ., 97/98, 815-825.

CHAPMAN, P.M. \& LONG, E.R. 1983, The use of bioassays as part of a comprehensive approach to marine pollution assessment. Mar. Poll. Bull., 14 (3): 81-84.

CRUZ, P; REIS, L.; BARROS, A.; NEVES, J. \& CÂMARA, F. 2007. Estudo comparativo da qualidade físico-química da água no período chuvoso e seco na confluência dos rios Poti e Parnaíba em Teresina/PI. In: Proceedings of II Congresso de Pesquisa e Inovação da Rede Norte Nordeste de Educação Tecnológica, João Pessoa, PB, Brasil. Available at: http://www.redenet.edu. br/publicacoes/arquivos/20080213_091110_MEIO-073.pdf

DELBON M.C. 2006, Ação da benzocaína e do óleo de cravo sobre os parâmetros fisiológicos de tilápia, Oreochromis niloticus. Dissertação (mestrado em aqüicultura) Centro de Aqüicultura da Unesp/Universidade Estadual Paulista Júlio de Mesquita Filho. Jaboticabal. São Paulo.

ERGENE-GÖZÜKARA, S; ÇAVAS T. \& AYMAK, C. 2001, Genotoxic evaluation of cypermethrin using the micronucleus test on Oreochromis niloticus, in: I. Akyurt, N. Basusta (Eds.), Proceedings of the 11th National Aquaculture Sypmosium, vol. 2, Musatafa Kemal University Press No. 8, Hatay, pp. 765-771 (in Turkish).

GRAVATO, C.; SANTOS, M.A. \& MAGALHÃES, I. 2000, Juvenile Dicentrarchus labrax L. biochemical and genotoxic responses after shot-term exposure to hnaphthoflavone and contaminated harbour waters. Fre. Environ.Bull., 9: 269 -274.

HARSHBARGER, J.C. \& CLARK, J.B. 1990, Epizootiology of neoplasms in bony fish of North- America. Sci. Total Environ., 94 (1-2): 1-32.

HEATH, A.G. 1995, Water pollution and fish physiology. London CRC Press, New York, 359 p.

HOOFTMAN, R.N. \& RAAT, W.K. 1982, Induction of nuclear anomalies (micronuclei) in the peripheral blood erythrocytes of the eastern mudminnow Umbra pygmaea by ethyl methanesulphonate. Mut. Res., 104: 147-52

HOSE, J.E.; CROSS, J.N.; SMITH, G.S. \& DIEHL, D. 1987, Elevated circulating erythrocyte micronuclei in fishes from contaminated sites off southern California. Mar. Environ. Res., 22: 167-766.

KIRSCHBAUM A.A.; SERIANI, R.; RANZANI-PAIVA, M.J.T.; ABESSA D.M.S. \& PEREIRA, C.D.S. 2009, Cytogenotoxicity biomarkers in fat snook Centropomus parallelus from Cananéia and São Vicente estuaries, SP, Brazil. Gen. Mol. Biol., 32: 151154. doi: 10.1590/S1415-47572009005000007

KNIE, J.L.W. \& LOPES, E.W.B., 2004, Testes Ecotoxicológicos: métodos, técnicas e aplicações. FATMA / GTZ, Florianópolis, $289 \mathrm{p}$.

KOROLEFF, F. 1976, Determination of ammonia. In: GRASSHOFF, E.; KREMLING, E. (Ed.). Methods of seawater analysis. New York: Verlag Chemie Weinhein, p. 117-181.

LIVINGSTONE, D.R. 2001, Contaminant-stimulated reactive oxygen species production and oxidative damage in aquatic organisms. Marine Pollution Bulletin, 42: 656-666.

METCALFE, C.D. 1988, Induction of micronuclei and nuclear abnormalities in the erythrocytes of mudminnow (Umbra limi) and brown bullheads (Ictalurus nebulosus). Bull. Environ.l Contamin. and Toxicol., 40: 489-495.

PACHECO, M. \& SANTOS, M.A. 1996, Induction of micronuclei and nuclear abnormalities in the erythrocytes of Anguilla anguilla L. exposed either to cyclophosphamide or to bleached kraft pulp mill effluent. Fres.Environ.Bull., 5: 746-751.

PACHECO, M. \& SANTOS, M.A. 1997, Induction of EROD activity and genotoxic effects by polycyclic aromatic hydrocarbons and resin acids on the juvenile eel (Anguilla anguilla L). Ecotoxicol. and Environ.l Saf., 38: 252-259. doi:10.1006/eesa.1997.1585

PACHECO, M. \& SANTOS, M.A. 1998. Induction of liver EROD and erythrocytic nuclear abnormalities by cyclophosphamide and PAHs in Anguilla anguilla L. Ecotoxicol Environ.Saf., 40: 71-76. doi:10.1006/eesa.1998.1644

PEREIRA, C.D.S.; ABESSA, D.M.S.; ZARONI, L.P.; GASPARRO, M.R.; BAINY, A.C.D.; BÍCEGO, M.C.; TANIGUCHI, S.; FURLEY, T.H. \& SOUSA, E.C.P.M. 2007, Integrated assessment of multi-level biomarker responses and chemical analysis in mussels from São Sebastião-SP-Brazil. Environ. Tox Chem., 26 (3): $462-469$

PICKERING, A.D. 1981, Stress and fish. London: Academic Press, p.277-293.

POWERS, D.A. 1989, Fish as model systems. Science, Washington, 246, 4928, p. 352-358,

RAND, G.M. 1995, Fundamentals of Aquatic Toxicology: effects, environmental fate and risk assessment. $2^{\text {nd }}$ Edition. Taylor \& Francis, Washington D.C., USA. 1125p.

ROSENFELD, G. 1947, Corante pancrômico para hematologia e citologia clínica. Nova combinação dos componentes do MayGrünwald e do Giemsa num só corante de emprego rápido. Mem.s Inst. Butantan, 20: 329-34.

SANCHEZ-GALAN， S.; LINDE，A.R.; IZQUIERDO, J.I. \& GARCIA-VAZQUEZ, E. 1998, Micronuclei and fluctuating asymmetry in brown trout (Salmo trutta): Complementary methods to biomonitor freshwater ecosystems. Mut. Res., 412: 219-225.

SERIANI, R.; ANDRADE, A.G.; SILVEIRA, F.L.; PINNA F.V.; CARVALHO, L.N. \& ROCHA, M.M. 2004, Aspectos sanitários, ecológicos e de saúde pública decorrente de florações das cianobactérias Microcystis aeruginosa e Cylindrospermopsis raciborskii. O Mundo da Saúde, 28 (4): 405-413.

SERIANI, R.; DIAS, D.C.; SILVA, M.R.R.; VILLARES, E.O.; ABESSA, D.M.S; MOREIRA, L.B; RANZANI-PAIVA, M.J.T. \& RIVERO, D.H.R.F. 2009. Hematological parameters of Oreochromis niloticus from a polluted site. Anals of World Aquaculture Society. Vera Cruz, México. Disponível em https://www.was.org/WASMeetings/meetings/ShowAbstract. aspx?Id=17603: acesso em 03/03/2010

WHITFIELD, M. 1974, The hydrolysis of ammonia ions in sea water - a theoretical study. Journal Marine Biological Association, UK 54: 565-580.

ZAR, J.H. 1984. Biostatistical Analysis. Prentice-Hall, Englewood Cliffs, NJ. 